\title{
МЕНЕДЖМЕНТ
}

УДК 658.147:330.142

DOI: $10.26565 / 2524-2547-2019-58-02$

\section{THE VALUE OF AN ENTERPRISE AND FORMATION OF REQUIREMENTS TO THE SYSTEM OF ITS ASSESSMENT INDICATORS}

\author{
Hanna Doroshenko \\ D.Sc. (Economics), Professor \\ V. N. Karazin Kharkiv National University \\ 4, Svobody Sq., Kharkiv, 61022, Ukraine \\ e-mail: anyadoroshenkonew@gmail.com \\ ORCID ID: 0000-0001-9971-2769
}

In modern conditions there is a strong need for theoretical and methodological generalizations and development, as well as practical recommendations, which would be aimed at building an effective mechanism for assessing the value of an enterprise in rapidly changing economic conditions. This study focuses on the part of this problem, especially the identification of the requirements to be met by the indicators used for such an assessment. In addition, in order to avoid unilateralism, the main approaches to determining the value of an enterprise are considered and its types are defined in the article. In our work, we rely on the concept of "enterprise value" in its broad sense. Value is a characteristic of production process encapsulated in economic wellbeing, which expresses its internal potential ability to bring effect that exceeds not only the cost of creating this benefit, but also its opportunity value, i.e. the benefit of lost opportunities as a result of investing resources in production of this benefit. The value becomes socially recognized if it allows the resource owner to have this effect in the form of accumulated economic added value based on economic profit. However, no matter what approach is used, the value of the assessment will depend on the right indicators that allow to make an analysis and to provide objective results. The main features of the system of indicators for assessing the value of an enterprise are: adequacy, accuracy, objectivity, trustworthiness, unambiguity, profitability, value, compatibility, timeliness and regularity, defining cause-and-effect links and indicators of assessment and evaluation of business opportunities. Taking into account the above-mentioned, the following conclusions are made: the choice of indicators for value assessing is individual in nature, as there are specific characteristics of appraisal objects and current and strategic objectives of the appraisal; to form a system for assessing the value of a particular joint-stock company, it is necessary to take into account the development or absence of market institutions, environment, factors of their stability, level of business capitalization, degree of control, etc.; usage (application) of a balanced system of assessment indicators should be the basis for making managerial decisions. The perspective for further research in this area needs to be guided in the development of tools for assessing the value of enterprises, as well as improving the integrated assessment of financial and economic conditions and efficiency of enterprise management, based on the highlighting of the most influential indicators of financial, property and management nature taking into account the specificity of an entity activity.

Keywords: Value of Enterprise, Indicators, Alternative Cost, Factors of Influence.

JEL Classification: G32; G30; L20; M20.

\section{ВАРТІСТЬ ПІДПРИЕМСТВА ТА ФОРМУВАННЯ ВИМОГ ДО СИСТЕМИ ПОКАЗНИКІВ ÏÏ ОЦІНКИ}

\author{
Дорошенко Ганна Оцександрівна \\ доктор економічних наук, професор \\ Харківсъкий національний університет імені В. Н. Каразіна \\ пл. Свободи, 4, Харків, 61022, Україна \\ e-mail: anyadoroshenkonew@gmail.com \\ ORCID ID: 0000-0001-9971-2769
}

У сучасних умовах гостро відчувається потреба у теоретико-методомогічних узагальненнях і розробках, а також у практичних рекомендаціях, які б були спрямовані на побудову дієвого механізму оцінки вартості підприємства в мінливих економічних умовах. У

(C) Doroshenko H., 2019 
роботі ми спираємося на поняття "вартість підприємства" у широкому значенні. Вартість це характеристика втіленого в економічному добробуті процесу виробництва, яка виражає його внутрішню потенційну здатність приносити ефект, що перевищує не тільки витрати на створення цього блага, а і його альтернативну вартість, тобто вигоду втрачених можливостей в результаті вкладення ресурсів у виробництво цього блага. Але, незалежно від того, який підхід використовується, цінність оцінки буде залежати від правильно підібраних показників, які дозволяють провести аналіз і отримати об'єктивні результати. Головними вимогами до показників оцінки вартості підприємств визначено: адекватність, точність, об'єктивність, достовірність, однозначність, економічність, порівнянність, своєчасність і регулярність, встановлення причино-наслідкових зв'язків показників оцінки й оціночної вартості підприємства. Враховуючи вищенаведене, зроблено наступні висновки: вибір показників оцінки вартості носить індивідуальний характер, що обумовлений специфрічними характеристиками суб'єктів оцінки й поточними та стратегічними цілями оцінки; для формування системи оцінки показників вартості підприємства необхідно враховувати фактори внутрішнього та зовнішнього середовища; використання збалансованої системи показників оцінки має стати основою дмя прийняття управлінських рішень. Перспективи подальших досліджень у даному напрямку доцільно вести у напрямку розвитку інструментарію оцінки вартості підприємств, а також вдосконалення інтегрального оцінювання фінансово-економічного стану та ефективності управління підприємством.

Кмючові слова: вартість підприємства, показники, альтернативна вартість, чинники впливу.

JEL Classification: G32; G30; L20; M20.

\title{
СТОИМОСТЬ ПРЕДПРИЯТИЯ И ФОРМИРОВАНИЕ ТРЕБОВАНИЙ К СИСТЕМЕ ПОКАЗАТЕАЕЙ ЕЕ ОЦЕНКИ
}

\author{
Дорошенко Анна Амександровна \\ доктор экономических наук, профессор \\ Харъковский национальный университет имени В. Н. Каразина \\ пл. Свободи, 4, Харьков, 61022, Украина \\ e-mail: anyadoroshenkonew@gmail.com \\ ORCID ID: 0000-0001-9971-2769
}

В современных условиях остро ощущается потребность в теоретико-методологических обобщениях, разработках, а также в практических рекомендациях, которые были бы направлены на построение эффективного механизма оценки стоимости предприятия в изменчивых экономических условиях. В работе мы опираемся на понятие «стоимость предприятия" в широком смысле. Стоимость - это характеристика воплощенного в экономическом благосостоянии процесса производства, которая выражает его внутреннюю потенциальную способность приносить эффект, превышающий не только затраты на создание этого блага, но и его альтернативную стоимость, то есть выгоду упущенных возможностей в результате вложения ресурсов в производство этого блага. Но, независимо от того, какой подход используется, ценность оценки будет зависеть от правильно подобранных показателей, позволяющих провести анализ и получить объективные результаты. Гцавными требованиями к показателям оценки стоимости предприятий явцяются адекватность, точность, объективность, достоверность, однозначность, экономичность, совместимость, своевременность и регулярность, установление причинно-следственных связей показателей оценки и оценочной стоимости предприятия. Учитывая вышеизложенное, сделаны следующие выводы: выбор показателей оценки стоимости носит индивидуальный характер, обусловленный специфическими характеристиками субъектов оценки, текущими и стратегическими целями оценки; для формирования системы оценки показателей стоимости предприятия необходимо учитывать факторы внутренней и внешней среды; использование сбалансированной системы показателей оценки должно стать основой для принятия управленческих решений. Перспективы дальнейших исследований в данном направлении целесообразно вести в направлении развития инструментария оценки стоимости предприятий, а также совершенствования интегральной оценки финансово-экономического состояния и эффективности управцения предприятием.

Кмючевые слова: стоимость предприятия, показатели, альтернативная стоимость, факторы влияния.

JEL Classification: G32; G30; L20; M20. 
Problem statement. The development of market relations, intensification of competition and overall uncertainty make the process of making effective management decisions a major competitive advantage. Particularly important in management process are the issues that consider determining the value of an enterprise. Solving such a problem requires a precise, reasonable and objective costs estimation, which will vary depending on a type of value selected.

In this regard, the part of diagnostics of the mechanism of an enterprise valuation effectiveness and formation of its management strategy is becoming more significant. In modern management the focus of attention shifts towards prompt response to changes in both external and internal environment.

Therefore, nowadays there is a strong need for theoretical and methodological generalizations and development, as well as practical recommendations, which would be aimed at building an effective mechanism for assessing the value of an enterprise in rapidly changing economic conditions. This study focuses on the part of this problem, especially the identification of the requirements to be met by the indicators used for such an assessment. In addition, in order to avoid unilateralism, the main approaches to determining the value of an enterprise are considered and its types are defined in the article.

Literature review. In modern scientific literature the issue of defining the concept of "value" is analyzed in the works of many economists. But the ambiguity of the interpretations suggests that there are different approaches to defining its essence. For example, S. V. Mocherniy considers value as an economic category that reflects the socially necessary labour and economic relations between the subjects of economic activity related to the social division of labour and the exchange of goods and services (Мочерний, 1996). According to Marshall - value is determined by supply and demand (Маршал, 1993); O. G. Mendrul considers the value of a business as the cost of an active business or the cost of $100 \%$ of corporate rights in an active business (Мендрул, 2002). V. M. Tarasevich describes value as s a monetary expression of products, services, factors of production costs in the process of exchange (Тарасевич, 2003). Also, the concept of value is considered at the level of legal acts: "Cost is the equivalent of value of an object assessment, expressed in the probable amount of money" (Кабінет Міністрів України, 2003).

Origins of the concept of value from the perspective of individual economic schools are: incurred costs - representatives of the labor theory of value, cost theory and theory of value in the conditions of information economy; price - representatives of the theory of marginal cost, the theory of demand and supply, the theory of factors of production; value - representatives of the theory of "equilibrium".

In this article, we rely on the concept of "enterprise value" in its broad sense. Value is a characteristic of production process encapsulated in the economic well-being, which expresses its internal potential ability to bring effect that exceeds not only the cost of creating this benefit, but also its opportunity value, i.e. the benefit of lost opportunities as a result of investing resources in production of this benefit. The value becomes socially recognized if it allows the resource owner to have this effect in the form of accumulated economic added value based on economic profit.

The purpose of the work is to develop practical recommendations for the formation of requirements to the system of an enterprise valuation indicators. Achievement of this goal requires the following tasks performance: analysis of existing approaches to the definition of the concept of cost, classification of factors affecting cost, determination of requirements for indicators of assessing the cost of an enterprise. The object of the study is the value of an enterprise. The subject is theoretical and practical aspects of determining the value of enterprises under uncertainty.

Research methodology. The methodological and theoretical basis of the study were the fundamental works of leading native and foreign scientists, devoted to the issues of valuation of enterprises and regulations in Ukraine. The philosophical principles of cognition, dialectics, logical and systematic approaches, induction, deduction, systematization, scientific abstraction and analogy became the methodological basis of the study.

Main results. For weak open economies, including Ukraine, the issue of an adequate valuation of enterprises which was formed at the center of contradictions at both macro- and micro-levels arises. First of all, it includes the underdevelopment of a stock market, information "closeness" of the most part of enterprises, profit shadowing and imperfect dividend policy. Purchase and sale of businesses, rights to control and management are nontransparent because there are no clear standards for preparing enterprises for sale, assessing their value, introducing squeeze-out procedures, forming institutions with independent corporate directors. Any transformations in the field of corporate governance or integration of enterprises contribute to specific threats or new influences that significantly change the value of an enterprise. 
Thus, "enterprise value" can be defined as an objective value that reflects the value of an enterprise as a specific product for a potential buyer and is formed on a certain date in an economic environment using accounting and market information to make the purchase and sale transaction possible on an open market.

Stably working developed markets are based on the concept of managing the company's value when making managerial decisions, which is based on meeting three basic criteria: ensuring the growth of a company's value; maximizing the value of a company; creating added value for investors.

An external consequence of the result of this process is the growth of a company's value. But for weak markets it is important to minimize losses and prevent business collapse or loss of control over it.

The value of an enterprise is a complex monetary characteristic of its value as a structurally organized integral system implementing economic activities. The company's value reflects the systemic result of its operation, the cumulative effect of different business lines and activities of individual business units, the consolidated result of all employees`efforts.

The value paradigm traditionally proceeds from the fact that management of enterprises should be aimed at maximizing their market value, which they often see as a market capitalization.

Ukrainian standards of assessment consider an enterprise value as the equivalent of an object assessment value. The value of an enterprise, in turn, is determined by its usefulness created in the process of purposeful activity of an enterprise.

In Ukraine, appraisers may, depending on a particular situation, use:

- market value of an existing enterprise;

- investment value of an operating enterprise;

- market value of shares (private interests);

- market value of the property complex;

- liquidation value of the property complex assets.

Other types of value are almost never applied in our country.

The most widely used concept is a "market value", which means the most likely price at which a given object can be alienated on the open market in a competitive environment, when the parties of the transaction act reasonably with all the necessary information, and extraordinary circumstances do not affect the amount of the transaction price.

However, in modern economic conditions, the market value of an enterprise as a target value in value management system is characterized by low objectivity when reflecting valueforming processes; significant separation from the real value of enterprises formed in their targeted financial and economic activities. Market value is a current (short-term) indicator of an enterprise value, weakly correlated with the strategic vectors of their development and does not take into account the interests of many stakeholders (except for the owners). Significant disadvantages of using market value for management purposes are also its high volatility, low level of control and possible application at a limited number of enterprises.

Investment value is the value of property for a specific investor under certain investment conditions. Investment value is an increase in the market value of an object as a result of investments in this project. Market and investment values are the same only when the expectations of an investor are typical for this market.

Liquidation value, or forced sale value, is the amount of money that can actually be received from the sale of property in a time that is too short for an adequate marketing in accordance with the definition of a market value.

The overwhelming majority of authors distinguish the following factors of influence on value:

1) external (inflation rate, political and economic crises, state of the national economy and its development trends, investment attractiveness of the country, competition, etc.) and internal (supply-demand ratio, investment attractiveness of both a valued company and a region, investment risks, liquidity of valued enterprises, degree of independence and capacity of an issuer, etc.);

2) macro-economic (general development trends of country's economy as a whole and stock market, state policy and certain actions of its institutions) and micro-economic (activities of an issuer and its counterparties);

3) financial (sales, cost, accounts receivable, inventory, etc.) and non-financial (goodwill, brand presence, personnel qualification, etc.);

4) material (non-current and current assets) and intangible (goodwill, organizational culture, personnel qualification, degree of innovation activity, etc.).

Analyzing the influence of these factors, we propose to divide them into two groups: generating and destroying. Value generating factors are a combination of conditions, parameters and circumstances that contribute to the effective functioning of an enterprise, growth of its competitiveness and synergistic effects in a combination of assets and liabilities and stimulate the growth of an enterprise value in general.

Value destroying factors are certain circumstances that worsen the stability of an enterprise, reduce its profitability, make it impossible to build an effective system for managing assets and liabilities, and have a negative effect on its value indicators.

It should also be noted that among the ex- 
perts, the approaches to estimating the value of the resulting indicators of appraisal are grouped as follows:

1. Cash flow valuation methods (FCF, $\mathrm{ECF}, \mathrm{CCF}, \mathrm{FTE})$.

2. Net value valuation methods (NPV, APV, SNPV).

3. Added value valuation methods (EVA, MVA, CVA).

However, no matter what approach is used, the value of the assessment will depend on the right indicators that allow to make an analysis and to provide objective results.

The main features of the system of indicators for assessing the value of an enterprise are:

- adequacy (the indicator should clearly indicate changes at an enterprise); accuracy (measurement errors should not lead to a distorted view of change in enterprise value);

objectivity (it is not allowed to use indicators which improved reporting values are possible once the real situation worsens; used indicators should minimize the desire of analysts or managers of an enterprise, distort the results of operations);

- trustworthiness (the way of information collecting and processing should provide the opportunity to verify the accuracy of data obtained during the process of independent monitoring and evaluation);

- unambiguity (the determination of an indicator should provide an equal understanding of the essence of the measured characteristic by both experts and all stakeholders);

profitability (reporting data should be obtained at the lowest possible costs; the indicators used should be based on collection of existing information as much as possible);

compatibility (the selection of indicators should be based on the need for continuous accumulation of data and ensuring their comparability for certain periods, as well as with indicators used in international practice);

- timeliness and regularity (reporting data must come with a strictly defined periodicity and a slight time lag between the moment of information collection and the term of its use;

- determination of cause-and-effect links, assessment indicators and the evaluation of business opportunities.

It should be noted that these targets should serve as the important conditions for choosing a particular indicator or indicators characterizing the degree of goals achievement: compliance of a specific goal with one or more indicators that are simple to calculate; chosen indicators should be predictable; value assessment indicators should be chosen so that their correlation among themselves is minimal; risk accounting factor is necessary in an unstable political and economic situation.

Current practice shows that both external and internal factors and mechanisms influence on the formation of an enterprise valuation mechanism. The legal mechanism and regulation of a stock market are the external procedures, and the formation of a mechanism for assessing the value of a joint stock company directly depends on the existing and effective mechanisms of share capital formation, corporate governance (Дорошенко \& Дорошенко, 2019) and a thoroughly developed mechanism for value management.

Summarizing of scientists' opinions led to the conclusion that the timely and correctly determined value of the enterprise is the basis for making sound managerial decisions to increase its competitiveness and investment attractiveness. But there is also an inverse relationship when tactical and strategic decisions cause the change in the value of an enterprise.

The operation of an enterprise, first of all, is aimed at obtaining results in key areas: operation, investment and its financial activities. Therefore, an integral assessment of these results characterizes the intrinsic value of an enterprise and should be reflected in its fundamental value.

Conclusions. Taking into account the abovementioned, the following conclusions are made:

the choice of indicators for assessing value is individual in nature, as there are specific characteristics of appraisal objects and current and strategic objectives of this appraisal;

to form a system for assessing the value of a particular joint-stock company, it is necessary to take into account the development or absence of market institutions, factors of their stability, environment, level of business capitalization, degree of control, etc.;

usage (application) of a balanced system of assessment indicators should be the basis for making managerial decisions.

The perspective for further research in this area needs to be guided in the development of tools for assessing the value of enterprises, as well as improving the integrated assessment of financial and economic condition and efficiency of enterprise management, based on the highlighting of the most influential indicators of financial, property and management nature taking into account the specificity of an entity activity. This enables a direct improvement of the process of an enterprise valuation, identification of potential opportunities and weaknesses of an enterprise and, accordingly, further influencing of an enterprise value. 


\section{Мiтepaтура}

1. Мочерний С. В. Основи економічних знань : підручник. Київ : Феміна, 1996. 352 с.

2. Маршал В. А. Принципы экономической науки : в 3 т. Москва : Прогресс, 1993. Т. 1. 415 с.

3. Мендрул О. Г. Управління вартістю підприємств : монографія. Київ : КНЕУ, 2002. 272 с.

4. Тарасевич В. М. Ценовая политика предприятия : монография. Санкт Петербур : Питер, 2003. 288 с.

5. Про затвердження Національного стандарту № 1 "Загальні засади оцінки майна і майнових прав" :

Постанова Кабінету Міністрів України від 10.09.2003 № 1440. URL: https://zakon.rada.gov.ua/laws/show/1440-2003\% D0\% ВF (дата звернення: 12.12.2019).

6. Дорошенко Г. О., Дорошенко О. Г. Корпоративний контроль у системі вартісно-орієнтованого управління підприємствами. Ефрективна економіка. 2019. № 6. URL: http://www.economy.nayka.com.ua/?op=1\&z=7093 (дата звернення: 12.12.2019).

7. Давидов О. І. Управління вартістю підприємств в умовах багатоваріантності іiі оцінки. Економічний nростір. 2015. № 104. С. 172-185.

8. КАюс Ю. І. Напрями розвитку корпоративного управління на промислових підприємствах. Науковий вісник Херсонсъкого державного університету. Економічні науки. 2015. № 13, ч. 1. С. 93-96.

9. Lampert M. Corporate social responsibility and the supposed moral agency of corporations. Ephemera. 2016. Vol. 16, issue 1. Pp. 79-105.

10. Freeman R. E., Moutchnik A. Stakeholder management and CSR: questions and answers. Umwelt Wirtschafts Forum. Springer Verlag. 2013. Vol. 21. № 1. Pp. 5-9.

\section{References}

1. Mochernij, S. V. (1996). Fundamentals of economic knowledge: a textbook. Kyiv: Femina, 1996. (in Ukrainian)

2. Marshal, V. A. (1993). Principles of Economic Science: 3 vols. Moscow: Progress. Vo1. 1. (in Russian)

3. Mendrul, O. G. (2002). Enterprise Cost Management: A Monograph. Kyiv: KNEU. (in Ukrainian)

4. Tarasevich, V. M. (2003). Enterprise Pricing: Monograph. Saint Petersburg: Piter. (in Russian)

5. The Cabinet of Ministers of Ukraine. (2003). On approval of the National Standard No. 1 "General Principles of Property and Property Rights Valuation": Resolution of the Cabinet of Ministers of Ukraine of September 10, 2003 No. 1440. Retrieved from https://zakon.rada.gov.ua/laws/show/1440-2003-\%D0\%BF. (in Ukrainian)

6. Doroshenko, H. O., \& Doroshenko, O. G. (2019). Corporate control in the system of value-oriented management of enterprises, Efektyvna ekonomika, 6. Retrieved from http://www.economy.nayka.com.ua/?op=1\&z=7093. (in Ukrainian)

7. Davydov, O. I. (2015). Management of the value of enterprises in terms of multi-variation of its assessment, Ekonomichnyy prostir, 104, 172-185. (in Ukrainian)

8. Klyus, Yu. I. (2015). Areas of development of corporate governance in industrial enterprises, Naukovyy visnyk Khersons'koho derzhavnoho universytetu. Ekonomichni nauky, 13(1), 93-96. (in Ukrainian)

9. Lampert, M. (2016). Corporate social responsibility and the supposed moral agency of corporations, Ephemera, 16(1), 79-105.

10. Freeman, R. E. \& Moutchnik, A. (2013). Stakeholder management and CSR: questions and answers, Umwelt Wirtschafts Forum. Springer Verlag, 21(1), 5-9. 